Article

\title{
Energy and Exergy Analysis of Low-Global Warming Potential Refrigerants as Replacement for R410A in Two-Speed Heat Pumps for Cold Climates
}

\author{
Bo Shen and Moonis R. Ally *(1) \\ Oak Ridge National Laboratory, Energy and Transportation Sciences Division, Oak Ridge, TN 37830, USA; \\ shenb@ornl.gov \\ * Correspondence: allymr@ornl.gov; Tel.: +1-865-576-8003
}

Received: 15 September 2020; Accepted: 24 October 2020; Published: 29 October 2020

\begin{abstract}
Heat pumps (HPs) are being developed with a new emphasis on cold climates. To lower the environmental impact of greenhouse gas (GHG) emissions, alternate low global warming potential (GWP) refrigerants must also replace the exclusive use of the refrigerant R410A, preferably without re-engineering the mechanical hardware. In this paper, we analyze the performance of four low-GWP alternative refrigerants (R32, R452B, R454B, and R466A) relative to the conventional R410A and draw conclusions on the relative performances for providing heating in cold climates based on the Air-Conditioning, Heating, and Refrigeration Institute (AHRI) 210/240 standard for two-speed heat pumps. The simulations are carried using the Department of Energy, Oak Ridge National Laboratory (DOE/ORNL) Heat Pump Design Model (HPDM), a well-known heating, ventilation, and air conditioning (HVAC) modeling and design tool in the public domain and the HVAC research and development community. The results of the simulation are further scrutinized using exergy analysis to identify sources of systemic inefficiency, the root cause of lost work. This rigorous approach provides an exhaustive analysis of alternate low-GWP refrigerants to replace R410A using available compressors and system components, without compromising performance.
\end{abstract}

Keywords: low-GWP refrigerants; modeling; heat pumps; simulation; exergy; cold climate

\section{Introduction}

The earth continues to experience record increases in surface temperatures, largely caused by anthropogenic activity. At the 21st Conference of the Parties in Paris 2015 (COP21), 188 countries reached an agreement to achieve global warming below $2{ }^{\circ} \mathrm{C}$ by the end of 2100 . A global phasedown of hydrofluorocarbons (HFCs) has been estimated to reduce warming by $0.5^{\circ} \mathrm{C}$, by 2100 . This paper addresses the research question of replacing currently used R410A with low global warming potential (low-GWP) refrigerants for cold climate heat pumps, in which there is a gap in current knowledge and performance assessment especially related to drop-in replacements. Exergy analysis of cold climate heat pumps at the component level provides greater insight into systemic inefficiency. Previous exergy-related studies have been limited to ordinary vapor compression heat pumps in conjunction with renewable energy sources, or incremental improvements through coupling, or using different refrigerants [1-13]. In this paper, the application in cold climate conditions, and operation at the temperature levels of the Air-Conditioning, Heating, and Refrigeration Institute (AHRI) 210/240 standard for two-speed heat pumps are new, relative to drop-in low-GWP refrigerants. To identify systemic inefficiency, a thermodynamic approach through exergy analysis is applied to heat pumps using renewable energy [14,15], to R22 substitution [16], to low-temperature heat sources [17], to sorption and ground-source or geothermal heat pumps [18,19], and to the general problem of heat 
pumps for simultaneous heating and cooling [20], but not to the specific issue of providing heating in cold climates based on the AHRI 210/240 standard for two-speed heat pumps by replacing R410A with low-GWP refrigerants.

Alternate, low-GWP replacements should have the following key characteristics: (1) a similar cooling/heating capacity per volumetric flow rate; (2) comparable or higher energy efficiency; (3) ability to work in the same temperature and pressure ranges; and (4) a resultant compressor discharge temperature that is similar or lower than the baseline refrigerant, and therefore, there is no need to change the compressor oil. Refrigerant fluid properties are significant for flow and wettability [21].

Table 1 depicts promising alternative refrigerants for R410A with much lower GWPs. The R410A replacements are mostly blends containing R32 and hydrofluoroolefin (HFO) R1234yf, as well as a pure refrigerant, R32. They have approximately $70 \%$ lower global warming potential (GWP) than R410A. Some compositions of R32 and R1234yf are mildly flammable and are classified as A2L. It should be noted that R466A is an A1 refrigerant, i.e., non-flammable [22]. These refrigerant blends have negligible temperature glides, i.e., deviation between the temperature starting condensation and starting evaporation at the same pressure. All the alternatives have higher critical temperatures than R410A, making them more suitable for high condensing temperature operation.

Table 1. Replacements for refrigerant R410A which have lower global warming potentials (GWPs) [22].

\begin{tabular}{ccccc}
\hline Refrigerant & GWP & Safety Category & Glide (K) & Critical T $\left({ }^{\circ} \mathrm{C}\right)$ \\
\hline $\mathrm{R} 32$ & 677 & A2L & 0.0 & 78.12 \\
\hline $\mathrm{R}^{2} 52 \mathrm{~B}{ }^{b}$ & 676 & A2L & 1.3 & 79.68 \\
\hline $\mathrm{R}^{2} 4 \mathrm{~B}^{c}$ & 467 & A2L & 1.5 & 77.0 \\
\hline $\mathrm{R}^{c} 66 \mathrm{~A}^{d}$ & 733 & A1 & 1.5 & 83.8 \\
\hline $\mathrm{R}{ }^{a} 10 \mathrm{~A}^{a}$ & 1924 & A1 & 0.1 & 71.34 \\
\hline
\end{tabular}

${ }^{a}$ R410A has compositions of R32 (0.5)/R125 (0.5), mass based; ${ }^{b}$ R452B has R32 (0.67)/R125 (0.07)/R1234yf (0.26), mass based; ${ }^{c}$ R454B has R32 (0.689)/R1234yf (0.311), mass based; ${ }^{d}$ R466A has R32 (0.49)/R125 (0.115)/R13I (0.395), mass based.

\section{Refrigerant Properties}

A candidate refrigerant should present the following two key characteristics: the enthalpy difference between saturated vapor line and the saturated liquid line (i.e., latent heat of vaporization) and the critical refrigerant temperature (to separate supercritical and subcritical working regions). In addition, volumetric heat of vaporization quantifies the cooling capacity per unit volumetric flow. Bigger volumetric capacity refrigerants lead to bigger cooling capacities if using the same compressor size.

Four refrigerants to replace R410A are compared in Figure 1 by temperature-enthalpy diagrams. All the replacements (except R466A) can tolerate higher critical temperatures and have wider domes, which means they are more suitable for high ambient operations. Figure 2 shows the volumetric heat of vaporization versus the average saturation temperature. R32 has noticeably larger volumetric heat of vaporization than R410A, and R466A is slightly larger. R452B and R454B have volumetric heats of vaporization slightly lower than that of R410A. When approaching the critical temperature from either side of the dome, the heat of vaporization drops until it vanishes at the critical point.

Saturation temperature versus density of R410A and the four alternative refrigerants are shown in Figure 3. All the alternatives, except for R466A, have lower suction vapor density and less refrigerant mass flow rate than R410A for a fixed compressor displacement volume. Lower volumetric capacity results in smaller capacity with the drop-in application and the same compressor. The saturation temperature is impacted by the heat transfer characteristics and refrigerant pressure drop. The smaller cooling capacity is also due to the lower saturation temperature in a drop-in application. 


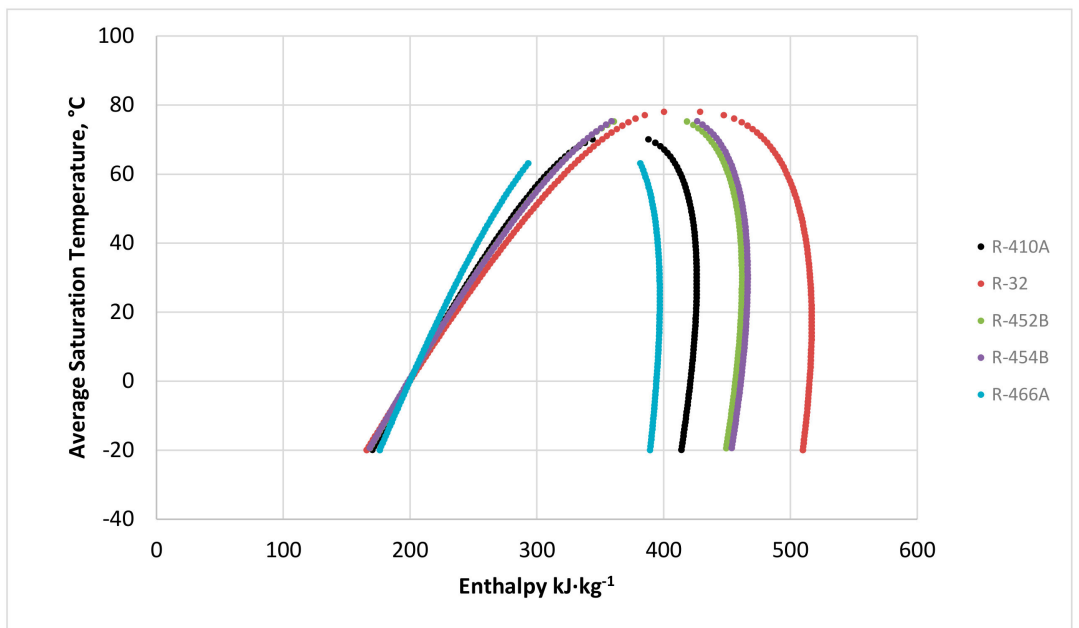

Figure 1. Temperature-enthalpy plots of refrigerant R410A and alternatives.

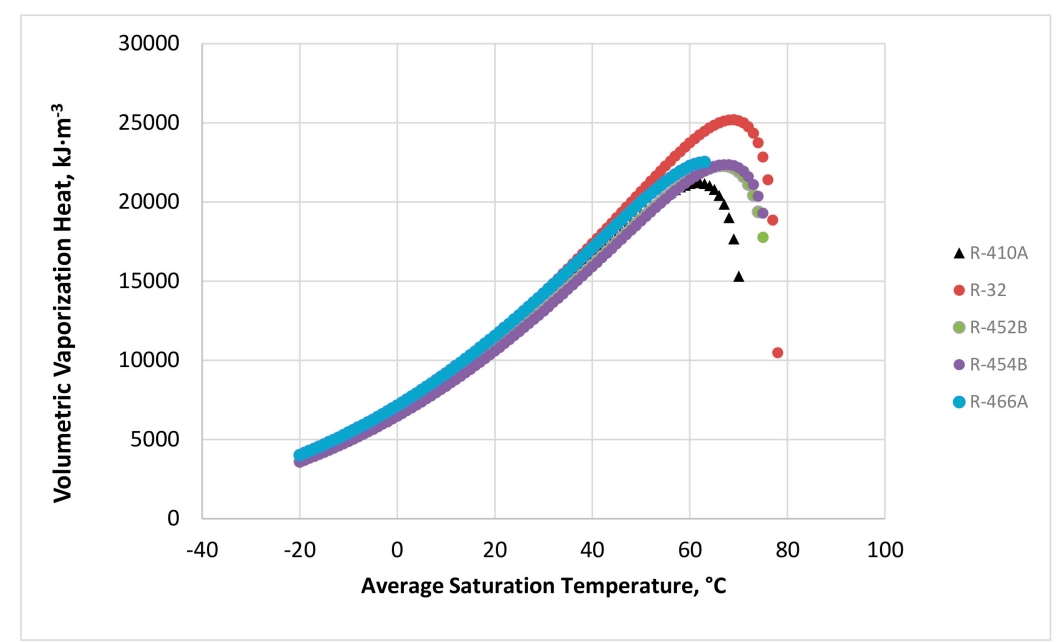

Figure 2. Volumetric heat of vaporization of refrigerant R410A and alternatives.

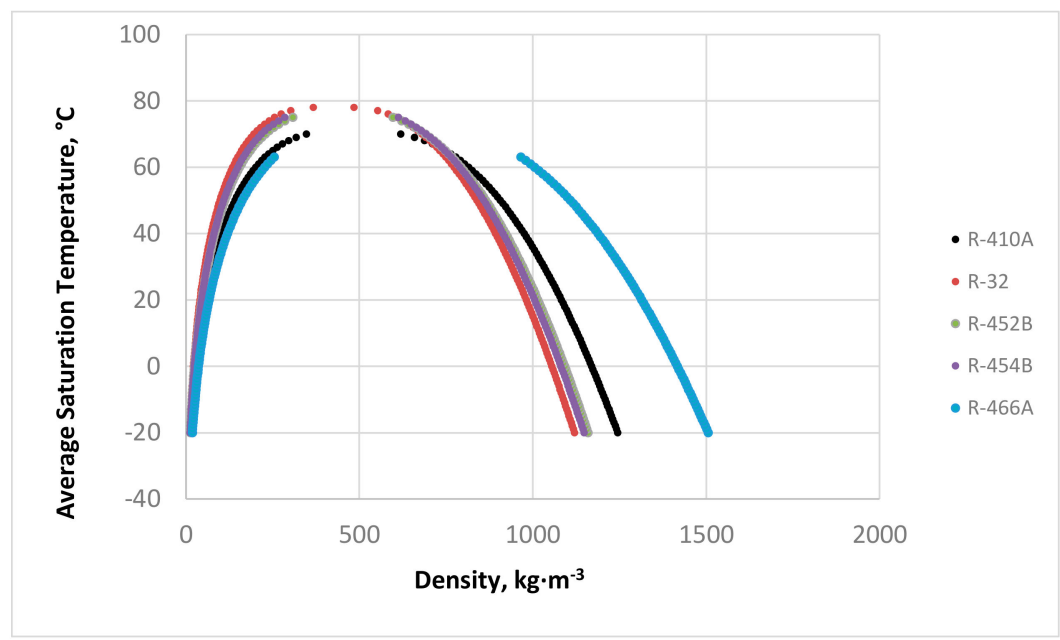

Figure 3. Saturation temperature-density plots of refrigerant R410A and alternatives.

\section{Model Description, Features, and Assumptions}

The Department of Energy, Oak Ridge National Laboratory (DOE/ORNL) Heat Pump Design Model [23] was used to model a baseline heat pump with R410A as the refrigerant. The heat pump 
system consists of a condenser, an evaporator, a thermo-expansion valve, and a compressor. Capabilities of the DOE/ORNL Heat Pump Design Model (HPDM), are described extensively in [23] and the salient features pertaining to this paper are described concisely below.

\subsection{Compressor Model}

The compressor power consumption and refrigerant mass flow rate were modeled using AHRI 10-coefficient compressor maps [24]. A compressor shell loss ratio, to the compressor power consumption is a user input to quantify the refrigerant energy gain in the compressor flow path. The predicted refrigerant flow rate is corrected by the real suction density, as described in [25]. The compressor map, originally developed for R410A, was used to model the alternative refrigerants. It was assumed that the compressor would maintain the same volumetric and isentropic efficiencies at the same suction and discharge pressures. Thus, the efficiencies were defined from the original R410A map as a function of the suction and discharge pressures, adopted by the alternative refrigerants in the same pressure range. The volumetric, and the isentropic efficiency are defined in Equations (1) and (2), respectively, as:

$$
\begin{gathered}
\eta_{\text {vol }}=m_{r} /\left(V_{\text {displacement }} \times S p_{\text {rotation }} \times D_{\text {suction }}\right) \\
\eta_{\text {isentropic }}=m_{r} \times\left(H_{\text {discharge, },}-H_{\text {suction }}\right) / P
\end{gathered}
$$

where $m_{r}$ is compressor mass flow rate, $\mathrm{kg} \cdot \mathrm{s}^{-1} ; P$ is compressor power, $\mathrm{W} ; \eta_{v o l}$ is the compressor volumetric efficiency; $S p_{\text {rotation }}$ is the compressor rotational speed, rotations per second; $D_{\text {suction }}$ is the suction refrigerant density, $\mathrm{kg} \cdot \mathrm{m}^{-3}$; $\eta_{\text {isentropic }}$ is compressor isentropic efficiency; $H_{\text {suction }}$ is the compressor suction enthalpy, $\mathrm{J} \cdot \mathrm{kg}^{-1}$; and $H_{\text {discharge, }}$ is the enthalpy, $\mathrm{J} \cdot \mathrm{kg}^{-1}$, obtained at the compressor discharge pressure and suction entropy. The approach of converting the compressor map of a baseline refrigerant used by its drop-in replacements has been extensively validated in [17]. The map conversion method for the alternative refrigerants reached similar accuracy as the compressor map developed for the original refrigerant.

\subsection{Heat Exchanger Model}

The fin-and-tube condenser is modeled using a segment-to-segment modeling approach, i.e., dividing one tube into multiple mini control volumes; each control volume considers air-side and refrigerant-side heat transfer and energy balance with possible phase change. Heat transfer within each control volume is calculated using an $\varepsilon$-NTU method. Pressure drops are considered in both the air side and refrigerant side. Figure 4 shows the diagram. The kth segment indicates a single segmented-control volume having energy transfer between the air side and refrigerant side. In addition, $m_{a, k}$ is the air flow rate across the segment, $h_{a, k, i}$ and $h_{a, k, o}$ are the air side inlet and outlet enthalpies, $m_{r, k}$ is the refrigerant side mass flow rate, $P_{r, k, i}$ and $P_{r, k, o}$ are the inlet and outlet refrigerant pressures, and $h_{r, k, i}$ and $h_{r, k, o}$ are the refrigerant side inlet and outlet enthalpies.

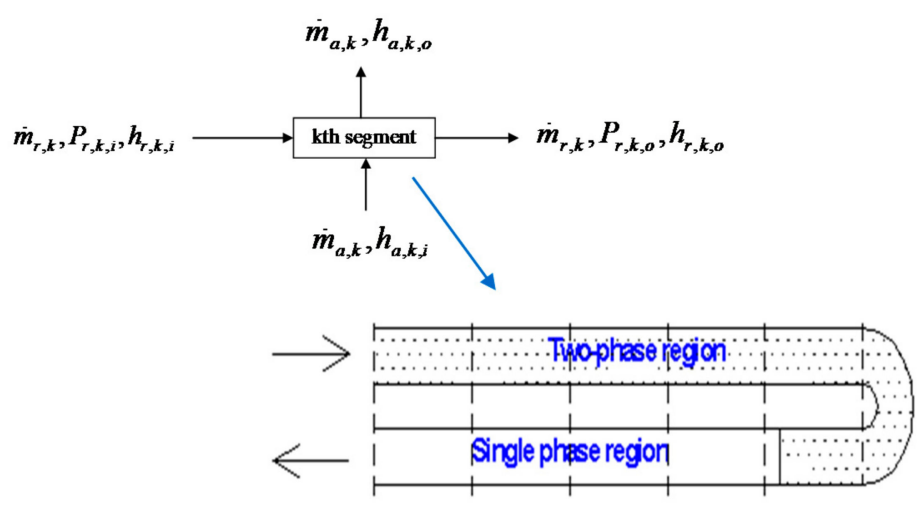

Figure 4. Segment-to-segment modeling approach. 
Using the same modeling approach as the segment-to-segment fin-tube condenser (Figure 4), the evaporator model additionally considers dehumidification. The method introduced by Braun et al. [26] was adopted to deal with water condensing on a cooling coil, where the heat and mass transfer was driven by the difference between specific enthalpies of the inlet air and saturated air at the refrigerant temperature. As noted, the mini segmental modeling approach could reveal the glide of a zeotropic refrigerant (refrigerant with a temperature glide between the onset of boiling and onset of condensation), since the temperature increment was accounted for by each individual segment along the refrigerant flow path.

Through an extensive literature survey, we identified heat transfer and pressure drop correlations suitable for modeling and optimizing air conditioners and heat pumps, and valid for various low GWP refrigerants. The references are listed in Table 2.

Table 2. Selected references describing correlations for two-phase heat transfer and pressure drop.

\begin{tabular}{cc}
\hline Application & Reference for Correlation \\
\hline Fin-and-tube heat exchanger (FTC) evaporation heat transfer & Thome [21] \\
\hline FTC condensation heat transfer & Cavallini et al. [27] \\
\hline FTC evaporation pressure drop & Choi et al. [28] \\
\hline FTC condensation pressure drop & Choi et al. [28] \\
\hline
\end{tabular}

The two-phase heat transfer correlations [21,27] account for local flow patterns, considering refrigerant properties. The idea of the flow-pattern dependent evaporation model is to first estimate the wetted surface inside a horizontal smooth tube using a flow map prediction. The model covers stratified flow; stratified wavy, annular wavy, intermittent, and annular flow; annular flow with partial dry out; and mist flow in evaporation. The general expression for local evaporating heat transfer coefficient is as follows:

$$
\begin{gathered}
h_{t p}=\frac{\theta_{d r y} h_{v}+\left(2 \pi-\theta_{d r y}\right) h_{w e t}}{2 \pi} \\
h_{\text {wet }}=\left(h_{n b}^{3}+h_{c b}^{3}\right)^{1 / 3} .
\end{gathered}
$$

In Equation (3), $\theta_{d r y}$ is the dry angle corresponding to the dry circumference of the tube, which is determined from the flow pattern and void fraction. The void fraction model for this correlation is described in [29]. In addition, $h_{\text {wet }}$ is the heat transfer coefficient at the wet circumference of the tube, which is composed of a nucleate boiling term $h_{n b}$ and a convective boiling term $h_{c b} ; h_{v}$ is the heat transfer coefficient at the dry circumference of the tube.

The local evaporation heat transfer coefficient calculated with the correlation of Thome [21] is shown in Figure 5. The correlation reasonably predicts degradation of heat transfer coefficient at high quality due to dry out of the liquid film, while most of the other correlations are not able to do so. This model can also reveal the effect of heat flux.

The local condensation heat transfer coefficient according to Cavallini [27] is given in Equation (5) as:

$$
h_{t p}=\frac{\theta_{f i l m} h_{f}+\left(2 \pi-\theta_{f i l m}\right) h_{c}}{2 \pi}
$$

where $\theta_{\text {film }}$ is the falling film angle around the perimeter of the tube, which is dependent on the local flow pattern and void fraction; $h_{f}$ is the Nusselt film condensation coefficient; and $h_{c}$ is the convective condensation heat transfer coefficient. The Cavallini [27] condensation correlation also starts with the flow pattern prediction, i.e., applying different heat transfer mechanisms specific to local flow patterns. 


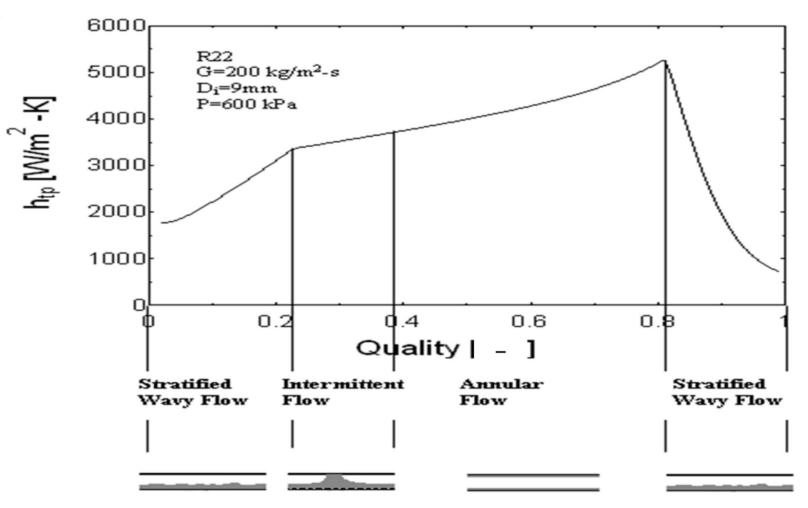

Figure 5. Local flow boiling coefficient predicted with the Thome [21] flow-pattern-dependent evaporation model.

It was assumed that azeotropic refrigerant (with negligible temperature glide) mixtures had similar heat transfer performances to those of pure refrigerants. Thus, pure refrigerant correlations can work for an azeotropic refrigerant mixture such as R410A. However, zeotropic refrigerant mixtures with large temperature glides, have different behaviors.

Heat transfer correlations developed for pure refrigerants must be corrected if they are to be used for zeotropic refrigerants. Stephan [30] proposed a correction method for condensation as well as evaporation. In this method, the mixture heat transfer coefficient $h_{m}$ is defined as:

$$
h_{m}=\left[1 / h_{f}+\left(\delta Q_{S V} / \delta Q_{T}\right) / h_{g}\right]^{-1}
$$

where $h_{f}$ is the heat transfer coefficient computed from a pure refrigerant heat transfer model; $h_{g}$ is the heat transfer coefficient of the vapor phase, which can be calculated with the Dittus-Boelter equation; and $\delta Q_{S V} / \delta Q_{T}$ is the ratio between the sensible heat transfer rate and the total heat transfer rate. Bell [31] suggested that if the total isobaric temperature glide was around $7-8{ }^{\circ} \mathrm{C}$, then the ratio could be approximated as:

$$
\left(\delta Q_{S V} / \delta Q_{T}\right) \approx x C p_{g}\left(\Delta T / \Delta h_{m}\right)
$$

where $\Delta T$ is the temperature glide, $\Delta h_{m}$ is the enthalpy of latent heat of the mixture, $x$ is the quality (mass fraction of vapor in an equilibrium mixture of vapor and liquid), and $C p_{g}$ is the vapor specific heat.

We adopted air-side heat transfer correlations specific to individual fin types for dry and wet surfaces. To simplify the models for the thermo-expansion valve, it was assumed that the liquid enthalpy ahead of the expansion device was equal to that at the evaporator inlet. The evaporator superheat degree and the condenser subcooling degree were direct inputs. A heat exchangers' airflow rate and corresponding fan power consumption were direct inputs from the laboratory measurements or from the manufacturer's data. Temperature changes and pressure drops of refrigerant lines, e.g., liquid, suction, and discharge lines were specified using the measured data from experiments. REFPROP 10.0 from Lemmon et al. [32] was used to calculate the refrigerant properties. New refrigerants can be modeled in REFPROP by creating a refrigerant definition file.

\subsection{Baseline Heat Pump and Rating Conditions}

The DOE/ORNL Heat Pump Design Model (HPDM) was used for analytical evaluations for a baseline pump having a two-speed compressor. The two-speed heat pump has the total cooling capacity of 5 ton $/ 17.6 \mathrm{~kW}$ at $35^{\circ} \mathrm{C}$ ambient temperature $/ 26.7^{\circ} \mathrm{C}$ indoor dry bulb temperature (DB) and $19.4^{\circ} \mathrm{C}$ indoor wet bulb temperature (WB). The high and low speeds of the scroll compressor provide $100 \% / 67 \%$ capacity. The indoor and outdoor heat exchangers are described in Table 3 . For the system modeling in, heating mode, the evaporator exit was assumed to have a constant superheat degree of $10 \mathrm{R}(5.6 \mathrm{~K})$. 
Table 3. Dimensions of indoor and outdoor fin-and-tube heat exchangers.

\begin{tabular}{ccc}
\hline Heat Exchangers & Condenser & Evaporator \\
\hline Frontal flow area, $\mathrm{ft} 2\left(\mathrm{~m}^{2}\right)$ & $3.30(0.307)$ & $22.3(2.07)$ \\
Total tube number & 84 & 64 \\
Number of rows & 3 (cross counterflow) & 2 (cross counterflow) \\
Parallel circuits & 9 circuits & 6 circuits \\
Density of fins & 168 fins $/ \mathrm{ft}(551$ fins $/ \mathrm{m})$ & 264 fins $/ \mathrm{ft}(866$ fins $/ \mathrm{m})$ \\
\hline Fan $/$ blower & Indoor $($ High/Low) & Outdoor \\
\hline Air flow, $\mathrm{ft}^{3} / \mathrm{min}^{2}\left(\mathrm{~m}^{3} / \mathrm{s}\right)$ & $1670(\mathrm{H}) / 1380(\mathrm{~L})(0.79 / 0.65)$ & $3500(1.65)(\mathrm{H} / \mathrm{L})$ \\
Power consumption $(\mathrm{W})$ & $322(\mathrm{H}) / 203(\mathrm{~L})$ & $300(\mathrm{H} / \mathrm{L})$ \\
\hline
\end{tabular}

The AHRI 210/240 [33] standard was used for two-speed heat pumps. In heating mode, the heat pump should be rated at the indoor dry bulb temperature of $21.1^{\circ} \mathrm{C}$. At the low speed, the ambient temperature should vary at $16.7{ }^{\circ} \mathrm{C} \mathrm{DB} / 13.6{ }^{\circ} \mathrm{C} \mathrm{WB}, 8.3^{\circ} \mathrm{C} \mathrm{DB} / 6.1^{\circ} \mathrm{C} \mathrm{WB}, 1.7^{\circ} \mathrm{C} \mathrm{DB} / 0.6$ ${ }^{\circ} \mathrm{C} \mathrm{WB}$, and $-8.3{ }^{\circ} \mathrm{C} \mathrm{DB} /-9.4{ }^{\circ} \mathrm{C} \mathrm{WB}$. The high speed should be rated at $8.3^{\circ} \mathrm{C} \mathrm{DB} / 6.1^{\circ} \mathrm{C} \mathrm{WB}$, $1.7^{\circ} \mathrm{C} \mathrm{DB} / 0.6^{\circ} \mathrm{C} \mathrm{WB}$, and $-8.3^{\circ} \mathrm{C} \mathrm{DB} /-9.4{ }^{\circ} \mathrm{C} \mathrm{WB}$.

Since HPDM is a steady-state system model, it does not predict cyclic performance and frost/defrost penalty. We adopted a typical degradation coefficient of 0.1 for the high speed, and 0.15 for the low speed. The AHRI 210/240 standard quantifies frosting/defrost loss at the outdoor condition of 1.7 ${ }^{\circ} \mathrm{C} \mathrm{DB} / 0.6^{\circ} \mathrm{C}$ WB. If no frost effect is correlated by an analytical model, the standard recommends a $98 \%$ factor to scale the power consumption and a $91 \%$ factor to scale the heating capacity. The AHRI $210 / 240$ standard assumes no frost formation at ambient temperatures above $8.3^{\circ} \mathrm{C} \mathrm{DB} / 6.1^{\circ} \mathrm{C}$ WB and below $-8.3^{\circ} \mathrm{C} \mathrm{DB} /-9.4^{\circ} \mathrm{C} \mathrm{WB}$. At other ambient conditions, the performances are interpolated between $8.3^{\circ} \mathrm{C} \mathrm{DB} / 6.1^{\circ} \mathrm{C} \mathrm{WB}$ and $1.7^{\circ} \mathrm{C} \mathrm{DB} / 0.6^{\circ} \mathrm{C} \mathrm{WB}$; and interpolated between $1.7^{\circ} \mathrm{C} \mathrm{DB} / 0.6^{\circ} \mathrm{C}$ $\mathrm{WB}$ and $-8.3^{\circ} \mathrm{C} \mathrm{DB} /-9.4^{\circ} \mathrm{C}$ WB. For the ambient conditions below $-8.3^{\circ} \mathrm{C} \mathrm{DB} /-9.4^{\circ} \mathrm{C} \mathrm{WB}$, the results are extrapolated based on the predicted results at $8.3^{\circ} \mathrm{C} \mathrm{DB} / 6.1^{\circ} \mathrm{C} \mathrm{WB}$ and $-8.3^{\circ} \mathrm{C} \mathrm{DB} /-9.4{ }^{\circ} \mathrm{C} \mathrm{WB}$.

Table 4 predicts heating performances using R410A at the low (_L) and high speed (_H), including heating capacities $(\mathrm{kW})$, heat pump heating coefficient of performances (COPs), compressor discharge temperatures, $\mathrm{T}\left({ }^{\circ} \mathrm{F} /{ }^{\circ} \mathrm{C}\right)$ and the compressor isentropic efficiency Equation (2). Comparing the high speed with the low speed at low ambient temperatures, the efficiency degradation is more pronounced because the loss factors ascend with the compressor pressure ratio. At $-8.3^{\circ} \mathrm{C}$, the isentropic efficiency decreases from $64 \%$ to $50 \%$. A typical heat pump sized to meet the building cooling load cannot satisfy heating load at low ambient temperatures.

Table 4. Predicted heating performance using R410A.

\begin{tabular}{ccccc}
\hline Outdoor Condition & Capacity $(\mathbf{k W})$ & $\mathbf{C O P}(\mathbf{W} / \mathbf{W})$ & Compressor Disc T $\left({ }^{\circ} \mathbf{F}\right] /\left[{ }^{\circ} \mathbf{C}\right)$ & Compressor Efficiency \\
\hline $8.3^{\circ} \mathrm{C} \_\mathrm{H}$ & 17.6 & 3.9 & $167.1 / 75.05$ & $72 \%$ \\
\hline $1.7^{\circ} \mathrm{C} \_\mathrm{H}$ & 15.0 & 3.6 & $166.7 / 74.83$ & $70 \%$ \\
\hline$-8.3^{\circ} \mathrm{C}_{-} \mathrm{H}$ & 11.4 & 3.0 & $172.8 / 78.22$ & $64 \%$ \\
\hline $16.7^{\circ} \mathrm{C} \_\mathrm{L}$ & 15.8 & 4.5 & $165.7 / 74.28$ & $66 \%$ \\
\hline $8.3^{\circ} \mathrm{C}$ L & 12.8 & 3.9 & $165.7 / 74.28$ & $63 \%$ \\
\hline $1.7^{\circ} \mathrm{C} \mathrm{L}$ & 10.8 & 3.4 & $170.1 / 76.72$ & $59 \%$ \\
\hline$-8.3^{\circ} \mathrm{C} \_\mathrm{L}$ & 7.9 & 2.6 & $190.8 / 88.22$ & $50 \%$ \\
\hline
\end{tabular}

Figure 6 compares the heat pump capacities as a function of the ambient temperature, versus the building load line of $\mathrm{DHR}_{\min }$ defined by the AHRI 210/240 standard for the ASHRAE climate zone IV. $\mathrm{DHR}_{\min }$ indicates a well-insulated building. Even in an adequately insulated home, the heat pump total capacity still cannot provide enough heating capacity. The high compressor speed will be called at an ambient temperature below $-3^{\circ} \mathrm{C}$. 


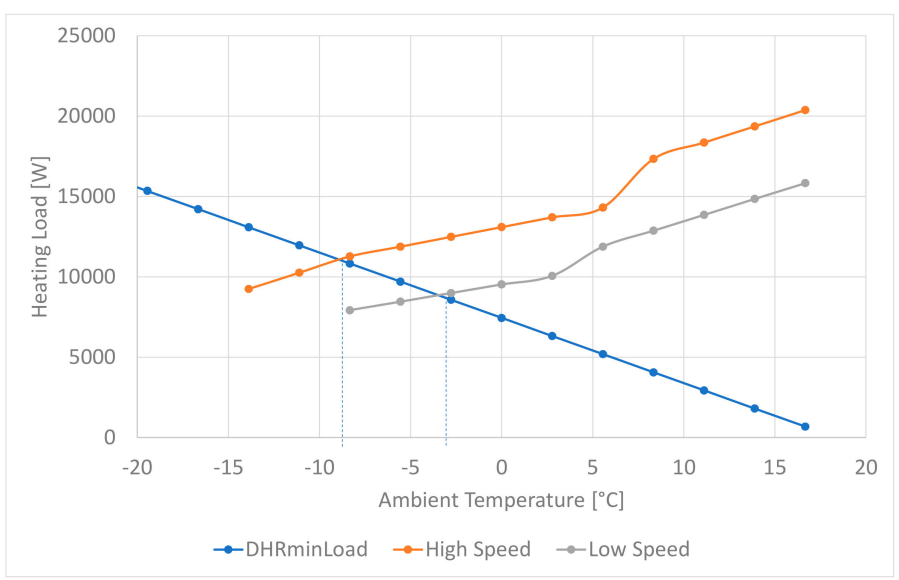

Figure 6. Heat pump capacities versus building load line.

The systemic COPs, based on the first law of thermodynamics, present a partial picture of energy efficiency. To investigate the sources of systemic inefficiency and where the opportunity of further efficiency improvements may be found, we perform an exergy analysis based on both the first and second laws of thermodynamics.

\section{General Mass, Energy, and Exergy Balances}

The general mass and energy balances equations are given by Equations (8) and (9), respectively,

$$
\begin{gathered}
\sum_{\text {out }} m_{r}-\sum_{\text {in }} m_{r}=0 \\
Q_{o}+W+\sum_{\text {in }}\left(h+\frac{v^{2}}{2}+g z\right) m_{r}-\sum_{\text {out }}\left(h+\frac{v^{2}}{2}+g z\right) m_{r}=0
\end{gathered}
$$

where $Q_{o}$ is the rate of thermal energy exchanged between the control volume $(\mathrm{CV})$ around a specific component of the heat pump and the surroundings at $T_{0} ; W$ is the rate of work input to the compressor; $h, v^{2} / 2$, and $g z$ represent specific enthalpy, kinetic energy, and potential energy, respectively; and $m_{r}$ is the refrigerant mass flow rate Equations (8) and (9) apply to steady-state steady flow conditions.

The general exergy balance equation [34-36] applied across each component under evaluation is,

$$
\sigma_{\text {Total }}=\sum_{\text {out }} m_{r} s-\sum_{\text {in }} m_{r} s-\frac{Q_{o}}{T_{o}} \geq 0
$$

where $\sigma_{\text {Total }}\left(\mathrm{W} \cdot \mathrm{K}^{-1}\right)$ is the sum of the entropy generation rates due to internal irreversibility and those from irreversible thermal energy transfer between the control volume surrounding each component and its surroundings. This method of exergy analysis of heat pumps has been validated and applied in low-GWP heat pumps, and in more complex cases of ground source heat pumps due to interaction with both the ground and the ambient air [37].

The irreversibility, which is the thermodynamic measure of the lost opportunity to do useful work, is the product of the ambient temperature, $T_{o}(\mathrm{~K})$, and the rate of entropy generation, $\sigma\left(\mathrm{W} \cdot \mathrm{K}^{-1}\right)$, is given by:

$$
I=T_{o} \sigma .
$$

The mass flow rate and values of state functions around the control volume for each heat pump component are obtained from the HPDM model and use of REFPROP 10. Application of Equations (8)-(11) to the particular heat pump component and its corresponding state points yield the component and systemic irreversibility shown in Tables 5-8. 
Table 5. Thermal and mechanical energy exchanges from the Department of Energy, Oak Ridge National Laboratory (DOE/ORNL) Heat Pump Design Model (HPDM) model and application of Equations (8)-(11), at $8.3^{\circ} \mathrm{C}$ ambient temperature.

\begin{tabular}{|c|c|c|c|c|c|c|c|c|c|c|c|}
\hline & & & $8.3^{\circ} \mathrm{C} \_\mathrm{H}$ & & & & & $8.3^{\circ} \mathrm{C} \_\mathrm{L}$ & & & \\
\hline & R410A & R32 & R452B & R454B & R466A & R410A & R32 & R452B & R454B & R466A & Units \\
\hline $\mathrm{m}$ & 287.67 & 206.50 & 235.60 & 229.25 & 340.70 & 203.47 & 145.94 & 166.00 & 161.50 & 242.39 & $\mathrm{~kg} \mathrm{~h}^{-1}$ \\
\hline $\mathrm{W}_{\text {refrig. }}$ & 3400.83 & 3729.48 & 3219.72 & 3176.54 & 3719.38 & 2485.10 & 2701.66 & 2352.23 & 2321.51 & 2700.51 & W \\
\hline$Q_{\text {Comp. }}$ & -437.30 & -479.56 & -408.46 & -408.46 & -478.27 & -319.87 & -347.74 & -302.77 & -298.81 & -347.59 & W \\
\hline $\mathrm{W}_{\text {Comp. }}$ & 3838.13 & 4209.04 & 3219.72 & 3585.00 & 4197.64 & 2804.97 & 3049.40 & 2655.00 & 2620.32 & 3048.10 & W \\
\hline$\sigma_{\text {Comp. }}$ & 3.37 & 3.66 & 3.15 & 3.13 & 3.66 & 3.26 & 3.48 & 3.09 & 3.05 & 3.48 & $\mathrm{~W} \mathrm{~K}^{-1}$ \\
\hline $\mathrm{I}_{\text {Comp. }}$ & 949.02 & 1029.42 & 887.52 & 881.19 & 1030.36 & 918.87 & 978.12 & 869.06 & 857.88 & 978.51 & $\mathrm{~W}$ \\
\hline$Q_{\text {Cond. }}$ & $-17,268.16$ & $-18,575.97$ & $-16,853.41$ & $-16,725.77$ & $-18,363.44$ & $-12,617.83$ & $-13,468.24$ & $-12,234.45$ & $-12,135.16$ & $-13,436.96$ & W \\
\hline$\sigma_{\text {Cond. }}$ & 4.62 & 5.51 & 4.46 & 4.40 & 5.24 & 3.03 & 3.59 & 2.90 & 2.87 & 3.45 & $\mathrm{~W} \mathrm{~K}^{-1}$ \\
\hline $\mathrm{I}_{\text {Cond. }}$ & 1358.91 & 1621.92 & 1313.20 & 1296.01 & 1541.10 & 890.89 & 1057.69 & 854.69 & 843.27 & 1014.00 & W \\
\hline $\mathrm{Q}_{\mathrm{EXV}}$ & -194.34 & -154.85 & -160.48 & -156.07 & -81.68 & -56.95 & -45.49 & -47.20 & -45.90 & -55.91 & W \\
\hline$\sigma_{\text {Exv. }}$ & 1.58 & 1.09 & 4.46 & 0.99 & 0.44 & 0.45 & 0.40 & 0.36 & 0.35 & 0.48 & $\mathrm{~W} \mathrm{~K}^{-1}$ \\
\hline $\mathrm{I}_{\mathrm{EXV}}$ & 352.80 & 306.81 & 289.30 & 279.64 & 123.14 & 126.25 & 112.29 & 101.39 & 97.65 & 134.51 & W \\
\hline$Q_{\text {Evap. }}$ & $14,151.71$ & $15,071.36$ & $13,863.20$ & $13,771.55$ & $14,920.87$ & $10,324.56$ & $10,918.83$ & $10,038.11$ & 9964.71 & $10,924.00$ & W \\
\hline$\sigma_{\text {Evap. }}$ & 1.58 & 1.68 & 1.51 & 1.49 & 1.74 & 0.91 & 0.97 & 0.87 & 0.87 & 0.99 & $\mathrm{~W} \mathrm{~K}^{-1}$ \\
\hline $\mathrm{I}_{\text {Evap. }}$ & 444.30 & 472.73 & 424.02 & 419.30 & 488.43 & 255.41 & 273.50 & 246.22 & 243.75 & 277.83 & W \\
\hline Line $\operatorname{Loss}_{(2-3)}$ & -90.04 & -70.05 & -69.03 & -66.27 & -86.80 & -59.36 & -46.45 & -46.11 & -44.30 & -57.49 & W \\
\hline$\sigma_{2-3}$ & 0.08 & 0.08 & 0.07 & 0.07 & 0.08 & 0.04 & 0.05 & 0.04 & 0.04 & 0.05 & $\mathrm{~W} \mathrm{~K}^{-1}$ \\
\hline $\mathrm{I}_{2-3}$ & 22.31 & 21.79 & 19.22 & 18.74 & 23.43 & 13.20 & 13.52 & 11.86 & 11.62 & 14.09 & $\mathrm{~W}$ \\
\hline Line $\operatorname{Loss}_{(6-1)}$ & 0.07 & 0.03 & 0.00 & 0.01 & -0.01 & 0.00 & 0.00 & 0.00 & 0.00 & 0.00 & W \\
\hline$\sigma_{6-1}$ & 0.07 & 0.07 & 0.07 & 0.07 & 0.07 & 0.05 & 0.04 & 0.05 & 0.05 & 0.05 & $\mathrm{~W} \mathrm{~K}^{-1}$ \\
\hline$I_{6-1}$ & 18.67 & 18.87 & 19.79 & 19.78 & 19.84 & 12.70 & 12.66 & 12.67 & 12.67 & 12.72 & W \\
\hline $\mathrm{I}_{\text {Total }}$ & 3146.00 & 3471.54 & 2953.04 & 2914.66 & 3226.30 & 2217.31 & 2447.79 & 2095.90 & 2066.83 & 2431.67 & $\mathrm{~W}$ \\
\hline $\mathrm{COP}_{\text {Carnot }}$ & 22.99 & 22.99 & 22.99 & 22.99 & 22.99 & 22.99 & 22.99 & 22.99 & 22.99 & 22.99 & \\
\hline $\mathrm{W}_{\text {Carnot }}$ & 751.17 & 808.06 & 733.13 & 727.58 & 798.82 & 548.88 & 585.87 & 532.20 & 527.88 & 584.51 & $\mathrm{~W}$ \\
\hline $\mathrm{W}_{\mathrm{a}}=\mathrm{W}_{\text {Carnot }}+\mathrm{I}_{\text {total }}$ & 3897.18 & 4279.60 & 3686.17 & 3642.24 & 4025.12 & 2766.19 & 3033.66 & 2628.10 & 2594.72 & 3016.18 & W \\
\hline $\mathrm{E}_{\text {In }}$ & $17,989.91$ & $19,280.44$ & $17,491.38$ & $17,356.57$ & $19,118.52$ & $13,129.52$ & $13,968.24$ & $12,693.10$ & $12,585.03$ & $13,972.10$ & W \\
\hline $\mathrm{E}_{\text {Out }}$ & $-17,989.84$ & $-19,280.44$ & $-17,491.38$ & $-17,356.57$ & $-19,010.19$ & $-13,054.01$ & $-13,907.92$ & $-12,630.52$ & $-12,524.16$ & $-13,897.95$ & W \\
\hline$\% \Delta \mathrm{E}$ & 0.00 & 0.00 & 0.00 & 0.00 & 0.57 & 0.58 & 0.43 & 0.49 & 0.48 & 0.53 & \\
\hline
\end{tabular}


Table 6. Thermal and mechanical energy exchanges from the HPDM model and application of Equations (8)-(11), at $1.7^{\circ} \mathrm{C}$ ambient temperature.

\begin{tabular}{|c|c|c|c|c|c|c|c|c|c|c|c|}
\hline & & & $1.7^{\circ} \mathrm{C} \_\mathrm{H}$ & & & & & $1.7^{\circ} \mathrm{C} \_\mathrm{L}$ & & & \\
\hline & R410A & R32 & R452B & R454B & R466A & R410A & R32 & R452B & R454B & R466A & Units \\
\hline $\mathrm{m}$ & 235.17 & 169.01 & 192.01 & 186.66 & 280.58 & 162.72 & 116.90 & 131.40 & 127.41 & 280.58 & $\mathrm{~kg} \mathrm{~h}^{-1}$ \\
\hline$W_{\text {refrig. }}$ & 3098.04 & 3382.92 & 2939.07 & 2901.31 & 3386.37 & 2330.46 & 2524.01 & 2212.69 & 2185.71 & 3386.37 & $\mathrm{~W}$ \\
\hline Q Comp. & -470.83 & -514.13 & -446.67 & -440.93 & -514.65 & -354.49 & -383.93 & -336.58 & -332.47 & -514.65 & W \\
\hline $\mathrm{W}_{\text {Comp. }}$ & 3568.87 & 3897.05 & 3385.74 & 3342.25 & 3901.03 & 2684.95 & 2907.94 & 2549.27 & 2518.18 & 3901.03 & W \\
\hline$\sigma_{\text {Comp. }}$ & 3.48 & 3.74 & 3.30 & 3.26 & 3.74 & 3.51 & 3.69 & 3.34 & 3.30 & 3.74 & $\mathrm{~W} \mathrm{~K}^{-1}$ \\
\hline $\mathrm{I}_{\text {Comp. }}$ & 956.75 & 1027.64 & 907.82 & 897.33 & 1027.42 & 963.48 & 1015.27 & 917.36 & 908.16 & 1027.42 & W \\
\hline$Q_{\text {Cond. }}$ & $-14,673.15$ & $-15,790.52$ & $-14,253.58$ & $-14,129.57$ & $-15,703.47$ & $-10,576.32$ & $-11,306.49$ & $-10,154.05$ & $-10,042.33$ & $-15,703.47$ & W \\
\hline$\sigma_{\text {Cond. }}$ & 3.50 & 4.24 & 3.38 & 3.33 & 4.02 & 2.29 & 2.79 & 2.19 & 2.16 & 4.02 & $\mathrm{~W} \mathrm{~K}^{-1}$ \\
\hline $\mathrm{I}_{\text {Cond. }}$ & 1028.51 & 1248.01 & 993.13 & 979.43 & 1184.07 & 672.66 & 819.52 & 644.59 & 634.73 & 778.68 & W \\
\hline $\mathrm{Q}_{\mathrm{EXV}}$ & -65.57 & -52.55 & -54.44 & -52.93 & -64.55 & -44.06 & -35.34 & -36.36 & -35.30 & -64.55 & $\mathrm{~W}$ \\
\hline$\sigma_{\text {Exv. }}$ & 0.82 & 0.72 & 0.67 & 0.65 & 0.85 & 0.44 & 0.38 & 0.36 & 0.35 & 0.85 & $\mathrm{~W} \mathrm{~K}^{-1}$ \\
\hline $\mathrm{I}_{\mathrm{EXV}}$ & 224.41 & 198.02 & 184.00 & 177.81 & 234.87 & 121.46 & 105.38 & 99.01 & 95.69 & 234.87 & $\mathrm{~W}$ \\
\hline $\mathrm{Q}_{\text {Evap. }}$ & $11,795.81$ & $12,583.37$ & $11,494.19$ & $11,402.34$ & $12,533.45$ & 8392.87 & 8899.77 & 8060.58 & 7971.98 & $12,533.45$ & $\mathrm{~W}$ \\
\hline$\sigma_{\text {Evap. }}$ & 1.22 & 1.30 & 1.16 & 1.15 & 1.36 & 0.69 & 0.74 & 0.69 & 0.69 & 1.36 & $\mathrm{~W} \mathrm{~K}^{-1}$ \\
\hline $\mathrm{I}_{\text {Evap. }}$ & 335.27 & 357.88 & 319.41 & 315.98 & 373.36 & 190.76 & 204.47 & 189.50 & 189.19 & 373.36 & W \\
\hline Line $\operatorname{Loss}_{(2-3)}$ & -68.17 & -53.54 & -53.05 & -50.96 & -66.20 & -44.53 & -35.08 & -34.64 & -33.28 & -66.20 & $\mathrm{~W}$ \\
\hline$\sigma_{2-3}$ & 0.05 & 0.05 & 0.05 & 0.05 & 0.06 & 0.04 & 0.04 & 0.03 & 0.03 & 0.06 & $\mathrm{~W} \mathrm{~K}^{-1}$ \\
\hline $\mathrm{I}_{2-3}$ & 15.33 & 15.99 & 13.85 & 13.58 & 16.53 & 10.73 & 11.21 & 9.78 & 9.60 & 16.53 & W \\
\hline Line $\operatorname{Loss}_{(6-1)}$ & 0.00 & 0.00 & -0.02 & -0.01 & -0.01 & 0.00 & 0.00 & -0.01 & 0.02 & -0.01 & W \\
\hline$\sigma_{6-1}$ & 0.07 & 0.07 & 0.07 & 0.07 & 0.07 & 0.04 & 0.04 & 0.04 & 0.04 & 0.07 & $\mathrm{~W} \mathrm{~K}^{-1}$ \\
\hline $\mathrm{I}_{6-1}$ & 18.57 & 18.55 & 18.48 & 18.47 & 18.65 & 12.26 & 12.24 & 12.21 & 12.20 & 18.65 & $\mathrm{~W}$ \\
\hline $\mathrm{I}_{\text {Total }}$ & 2578.84 & 2866.10 & 2436.70 & 2402.60 & 2854.89 & 1971.35 & 2168.09 & 1872.45 & 1849.57 & 2854.89 & W \\
\hline $\mathrm{COP}_{\text {Carnot }}$ & 15.17 & 15.17 & 15.17 & 15.17 & 15.17 & 15.17 & 15.17 & 15.17 & 15.17 & 15.17 & \\
\hline $\mathrm{W}_{\text {Carnot }}$ & 967.41 & 1041.07 & 939.74 & 931.57 & 1035.34 & 697.30 & 745.44 & 669.46 & 662.09 & 1035.34 & W \\
\hline $\mathrm{W}_{\mathrm{a}}=\mathrm{W}_{\text {Carnot }}+\mathrm{I}_{\text {total }}$ & 3546.25 & 3907.17 & 3376.45 & 3334.17 & 3890.23 & 2668.65 & 2913.53 & 2541.91 & 2511.66 & 3890.23 & W \\
\hline $\mathrm{E}_{\text {In }}$ & $15,364.68$ & $16,480.42$ & $14,879.91$ & $14,744.58$ & $16,434.48$ & $11,077.81$ & $11,807.71$ & $10,609.84$ & $10,490.18$ & $16,434.48$ & $\mathrm{~W}$ \\
\hline $\mathrm{E}_{\text {Out }}$ & $-15,277.73$ & $-16,410.74$ & $-14,807.73$ & $-14,674.40$ & $-16,348.87$ & $-11,019.40$ & $-11,760.84$ & $-10,561.62$ & $-10,443.37$ & $-16,348.87$ & W \\
\hline$\% \Delta \mathrm{E}$ & 0.57 & 0.42 & 0.49 & 0.48 & 0.52 & 0.53 & 0.40 & 0.45 & 0.45 & 0.52 & \\
\hline
\end{tabular}


Table 7. Thermal and mechanical energy exchanges from the HPDM model and application of Equations (8)-(11), at $-8.3^{\circ} \mathrm{C}$ ambient temperature.

\begin{tabular}{|c|c|c|c|c|c|c|c|c|c|c|c|}
\hline & & & $-8.3^{\circ} \mathrm{C} \_\mathrm{H}$ & & & & & $-8.3^{\circ} \mathrm{C} \_\mathrm{L}$ & & & \\
\hline & R410A & R32 & R452B & R454B & R466A & R410A & R32 & R452B & R454B & R466A & Units \\
\hline $\mathrm{m}$ & 166.54 & 120.02 & 134.40 & 130.33 & 201.49 & 108.12 & 78.04 & 86.26 & 83.51 & 132.44 & $\mathrm{~kg} \mathrm{~h}^{-1}$ \\
\hline$W_{\text {refrig. }}$ & 2712.30 & 2950.75 & 2580.70 & 2549.95 & 2963.76 & 2139.94 & 2309.36 & 2053.74 & 2034.71 & 2316.50 & $\mathrm{~W}$ \\
\hline Q Comp. & -512.47 & -557.52 & -487.61 & -481.79 & -559.97 & -404.63 & -436.66 & -388.33 & -384.73 & -438.01 & W \\
\hline $\mathrm{W}_{\text {Comp. }}$ & 3224.77 & 3508.27 & 3068.31 & 3031.74 & 3523.73 & 2544.57 & 2746.02 & 2442.06 & 2419.44 & 2754.51 & W \\
\hline$\sigma_{\text {Comp. }}$ & 3.83 & 4.06 & 3.66 & 3.63 & 4.06 & 4.05 & 4.20 & 3.90 & 3.87 & 4.23 & $\mathrm{~W} \mathrm{~K}^{-1}$ \\
\hline $\mathrm{I}_{\text {Comp. }}$ & 1014.21 & 1073.99 & 969.57 & 960.41 & 1075.96 & 1073.58 & 1112.96 & 1032.04 & 1024.23 & 1121.31 & W \\
\hline$Q_{\text {Cond. }}$ & $-11,091.63$ & $-11,972.46$ & $-10,647.95$ & $-10,529.69$ & $-12,019.48$ & -7710.13 & -8289.89 & -7328.06 & -7238.04 & -8406.65 & W \\
\hline$\sigma_{\text {Cond. }}$ & 2.26 & 2.87 & 2.20 & 2.17 & 2.68 & 1.53 & 1.99 & 1.53 & 1.53 & 1.82 & $\mathrm{~W} \mathrm{~K}^{-1}$ \\
\hline $\mathrm{I}_{\text {Cond. }}$ & 665.83 & 844.35 & 647.40 & 638.77 & 787.62 & 451.60 & 586.40 & 451.65 & 448.92 & 536.42 & W \\
\hline $\mathrm{Q}_{\mathrm{EXV}}$ & -44.37 & -35.75 & -36.73 & -35.68 & -44.18 & -28.21 & -22.77 & -23.19 & -22.52 & -28.37 & $\mathrm{~W}$ \\
\hline$\sigma_{\text {Exv. }}$ & 0.75 & 0.65 & 0.63 & 0.61 & 0.78 & 0.42 & 0.35 & 0.36 & 0.35 & 0.43 & $\mathrm{~W} \mathrm{~K}^{-1}$ \\
\hline $\mathrm{I}_{\mathrm{EXV}}$ & 199.26 & 171.50 & 165.59 & 160.69 & 206.39 & 111.54 & 93.94 & 94.10 & 91.83 & 115.21 & $\mathrm{~W}$ \\
\hline $\mathrm{Q}_{\text {Evap. }}$ & 8526.75 & 9139.90 & 8187.29 & 8096.05 & 9202.03 & 5663.34 & 6055.37 & 5349.79 & 5276.41 & 6183.52 & $\mathrm{~W}$ \\
\hline$\sigma_{\text {Evap. }}$ & 0.80 & 0.86 & 0.78 & 0.78 & 0.91 & 0.47 & 0.50 & 0.48 & 0.48 & 0.51 & $\mathrm{~W} \mathrm{~K}^{-1}$ \\
\hline $\mathrm{I}_{\text {Evap. }}$ & 212.76 & 227.19 & 207.54 & 206.32 & 239.77 & 124.04 & 131.80 & 126.53 & 126.54 & 135.69 & W \\
\hline Line $\operatorname{Loss}_{(2-3)}$ & -44.21 & -35.03 & -34.62 & -33.33 & -43.53 & -27.53 & -21.87 & -21.52 & -20.72 & -27.38 & $\mathrm{~W}$ \\
\hline$\sigma_{2-3}$ & 0.04 & 0.04 & 0.03 & 0.03 & 0.04 & 0.03 & 0.03 & 0.02 & 0.02 & 0.03 & $\mathrm{~W} \mathrm{~K}^{-1}$ \\
\hline $\mathrm{I}_{2-3}$ & 11.15 & 11.93 & 10.28 & 10.11 & 12.18 & 7.95 & 8.44 & 7.35 & 7.23 & 8.66 & W \\
\hline Line $\operatorname{Loss}_{(6-1)}$ & 0.00 & 0.00 & 0.00 & 0.01 & -0.01 & 0.00 & 0.00 & 0.00 & 0.00 & 0.00 & W \\
\hline$\sigma_{6-1}$ & 0.07 & 0.07 & 0.07 & 0.07 & 0.07 & 0.04 & 0.04 & 0.04 & 0.04 & 0.04 & $\mathrm{~W} \mathrm{~K}^{-1}$ \\
\hline $\mathrm{I}_{6-1}$ & 17.72 & 17.73 & 17.58 & 17.56 & 17.87 & 11.26 & 11.24 & 11.17 & 11.15 & 11.39 & W \\
\hline $\mathrm{I}_{\text {Total }}$ & 2120.93 & 2346.69 & 2017.97 & 1993.86 & 2339.78 & 1779.97 & 1944.78 & 1722.84 & 1709.90 & 1928.67 & W \\
\hline $\mathrm{COP}_{\text {Carnot }}$ & 10.01 & 10.01 & 10.01 & 10.01 & 10.01 & 10.01 & 10.01 & 10.01 & 10.01 & 10.01 & \\
\hline $\mathrm{W}_{\text {Carnot }}$ & 1108.22 & 1196.23 & 1063.89 & 1052.07 & 1200.93 & 770.36 & 828.28 & 732.18 & 723.19 & 839.95 & W \\
\hline $\mathrm{W}_{\mathrm{a}}=\mathrm{W}_{\text {Carnot }}+\mathrm{I}_{\text {total }}$ & 3229.15 & 3542.92 & 3081.86 & 3045.93 & 3540.71 & 2550.32 & 2773.07 & 2455.02 & 2433.09 & 2768.62 & W \\
\hline $\mathrm{E}_{\text {In }}$ & $11,751.52$ & $12,648.17$ & $11,255.61$ & $11,127.81$ & $12,725.76$ & 8207.90 & 8801.39 & 7791.85 & 7695.85 & 8938.04 & $\mathrm{~W}$ \\
\hline $\mathrm{E}_{\text {Out }}$ & $-11,692.68$ & $-12,600.77$ & $-11,206.91$ & $-11,080.49$ & $-12,667.17$ & -8170.49 & -8771.19 & -7761.10 & -7666.00 & -8900.42 & W \\
\hline$\% \Delta \mathrm{E}$ & 0.50 & 0.37 & 0.43 & 0.43 & 0.46 & 0.46 & 0.34 & 0.39 & 0.39 & 0.42 & \\
\hline
\end{tabular}


Table 8. Thermal and mechanical energy exchanges from the HPDM model and application of Equations (8)-(11), at $16.7^{\circ} \mathrm{C}$ ambient temperature.

\begin{tabular}{|c|c|c|c|c|c|c|}
\hline & & & $16.7^{\circ} \mathrm{C} \_\mathrm{L}$ & & & \\
\hline & R410A & R32 & R452B & R454B & R466A & Units \\
\hline $\mathrm{m}$ & 265.53 & 190.27 & 216.85 & 211.02 & 313.25 & $\mathrm{~kg} \mathrm{~h}^{-1}$ \\
\hline$W_{\text {refrig. }}$ & 2737.30 & 2996.44 & 2578.87 & 2542.82 & 2980.21 & W \\
\hline$Q_{\text {Comp. }}$ & -270.55 & -296.17 & -254.89 & -251.33 & -294.57 & $\mathrm{~W}$ \\
\hline $\mathrm{W}_{\text {Comp. }}$ & 3007.85 & 3292.61 & 2833.76 & 2794.15 & 3274.77 & W \\
\hline$\sigma_{\text {Comp. }}$ & 3.12 & 3.36 & 2.92 & 2.88 & 3.37 & $\mathrm{~W} \mathrm{~K}^{-1}$ \\
\hline $\mathrm{I}_{\text {Comp. }}$ & 904.12 & 974.69 & 847.14 & 835.55 & 976.49 & W \\
\hline$Q_{\text {Cond. }}$ & $-15,559.73$ & $-16,607.34$ & $-15,148.58$ & $-15,037.18$ & $-16,431.36$ & W \\
\hline$\sigma_{\text {Cond. }}$ & 4.35 & 5.06 & 4.17 & 4.11 & 4.85 & $\mathrm{~W} \mathrm{~K}^{-1}$ \\
\hline $\mathrm{I}_{\text {Cond. }}$ & 1278.89 & 1489.78 & 1225.85 & 1210.00 & 1427.64 & W \\
\hline $\mathrm{Q}_{\mathrm{EXV}}$ & -78.71 & -62.55 & -64.47 & -62.68 & -76.70 & W \\
\hline$\sigma_{\text {Exv. }}$ & 0.45 & 0.42 & 0.36 & 0.34 & 0.49 & $\mathrm{~W} \mathrm{~K}^{-1}$ \\
\hline $\mathrm{I}_{\mathrm{EXV}}$ & 130.05 & 121.09 & 103.37 & 98.89 & 141.07 & W \\
\hline$Q_{\text {Evap. }}$ & $13,091.96$ & $13,823.21$ & $12,785.00$ & $12,702.77$ & $13,712.32$ & W \\
\hline$\sigma_{\text {Evap. }}$ & 1.17 & 1.26 & 1.15 & 1.14 & 1.28 & $\mathrm{~W} \mathrm{~K}^{-1}$ \\
\hline $\mathrm{I}_{\text {Evap. }}$ & 340.08 & 366.64 & 334.52 & 331.03 & 370.76 & W \\
\hline Line $\operatorname{Loss}_{(2-3)}$ & -86.45 & -66.81 & -65.33 & -62.61 & -82.75 & W \\
\hline$\sigma_{2-3}$ & 0.06 & 0.06 & 0.05 & 0.05 & 0.06 & $\mathrm{~W} \mathrm{~K}^{-1}$ \\
\hline $\mathrm{I}_{2-3}$ & 17.85 & 17.68 & 15.41 & 15.04 & 18.78 & W \\
\hline Line $\operatorname{Loss}_{(6-1)}$ & 0.00 & 0.00 & -0.01 & -0.01 & 0.00 & W \\
\hline$\sigma_{6-1}$ & 0.04 & 0.04 & 0.05 & 0.05 & 0.04 & $\mathrm{~W} \mathrm{~K}^{-1}$ \\
\hline $\mathrm{I}_{6-1}$ & 13.03 & 12.99 & 13.05 & 13.05 & 13.01 & W \\
\hline $\mathrm{I}_{\text {Total }}$ & 2684.03 & 2982.87 & 2539.34 & 2503.56 & 2947.75 & W \\
\hline $\mathrm{COP}_{\text {Carnot }}$ & 65.39 & 66.88 & 66.88 & 66.88 & 66.88 & \\
\hline $\mathrm{W}_{\text {Carnot }}$ & 237.96 & 248.33 & 226.52 & 224.86 & 245.70 & $\mathrm{~W}$ \\
\hline $\mathrm{W}_{\mathrm{a}}=\mathrm{W}_{\text {Carnot }}+\mathrm{I}_{\text {total }}$ & 2921.99 & 3231.20 & 2765.87 & 2728.42 & 3193.46 & $\mathrm{~W}$ \\
\hline $\mathrm{E}_{\text {In }}$ & $16,099.81$ & $17,115.82$ & $15,618.75$ & $15,496.91$ & $16,987.10$ & $\mathrm{~W}$ \\
\hline$E_{\text {Out }}$ & $-15,995.44$ & $-17,032.87$ & $-15,533.27$ & $-15,413.80$ & $-16,885.39$ & W \\
\hline$\% \Delta \mathrm{E}$ & 0.65 & 0.48 & 0.55 & 0.54 & 0.60 & \\
\hline
\end{tabular}

\section{Energy, Entropy Generation, and Irreversibility Calculations}

The work input to the compressor obtained from the HPDM model for each outdoor temperature is the algebraic sum of $W_{\text {Refrig.. }}$ and $Q_{\text {Comp }}$ which equals $W_{\text {Comp., }}$ as shown in Tables 5-8. The negative sign for $Q_{\text {Comp }}$ is because heat is flowing out of the compressor $\mathrm{CV}$, as per the International Union of Pure and Applied Chemistry (IUPAC) convention (energy inflow is positive, outflow is negative). From entropy generation rate, $\sigma_{\text {Comp. }}$ the total compressor irreversibility, $I_{\text {Comp. }}=T_{o} \sigma_{\text {Comp. }}$, where $T_{o}$ is the ambient temperature specified at the top of Tables 5-8 which must be converted to absolute temperature for use in Equations (10) and (11).

For a rigorous analysis, we must show consistency between the compressor work input ( $W_{\text {Comp. }}$ ) from the HPDM model and that calculated from irreversibility analysis. The total actual work input to the compressor must be the sum of the Carnot work and the irreversibility losses. The Carnot work for an ideal heat pump with no irreversibility is given by:

$$
\operatorname{COP}_{\text {Carnot }}=\frac{T_{h}}{\left(T_{h}-T_{L}\right)}
$$

where $T_{h}$ is the set temperature $\left(21.1^{\circ} \mathrm{C}\right)$ of the conditioned space during heating and $T_{L}$ is the outdoor temperature indicated on the header of Tables 5-8. The total cyclic irreversibility, $I_{\text {Total }}$, is the sum of the irreversibility of each component, i.e., the compressor, condenser, expansion valve (EXV), and line loss between the evaporator and the compressor inlet $\left(I_{6-1}\right)$ and the line loss from the compressor 
outlet to the evaporator inlet, $\left(I_{2-3}\right)$. The actual work input must be the sum of the ideal work (Carnot work) and the lost work due to irreversibility.

Thus, $W_{a}=W_{\text {Carnot }}+I_{\text {Total }}$ and is in reasonable agreement with the work input to the heat pump, $W_{\text {Comp }}$. derived from the model. This calculation is performed for each ambient temperature as per the AHRI 210/240 standard. We emphasize that the work computed from irreversibility analysis for the heat pump cycle and that obtained from the HPDM model are consistent, complementary, and validate our analyses based on both the first and second laws of thermodynamics.

\section{Component-Wise Irreversibility}

More detailed information on the systemic irreversibility is derived from the component-level irreversibility for each temperature level in the AHRI 210/240 standard, as shown in Figure 7. The structure of component-level irreversibility between the high and low speeds at $8.3^{\circ} \mathrm{C}$ ambient temperature is markedly different, i.e., condenser irreversibility is greater than compressor irreversibility for all refrigerants. The total irreversibility is also higher for the high speed vs. the low speed, as might be expected (rapid processes have higher entropy losses). The irreversibility structure for $1.7^{\circ} \mathrm{C}$ high and low speeds are similar in structure with the overall irreversibility at the high speed greater than at the low speed. For the coldest ambient case of $-8.3^{\circ} \mathrm{C}$, again the structure of the irreversibility remains similar for the high and low speeds but notably, the compressor irreversibility is of the same magnitude, but the condenser and evaporator irreversibility is smaller for the lower speed versus the higher speed due to smaller condenser and evaporator loads.
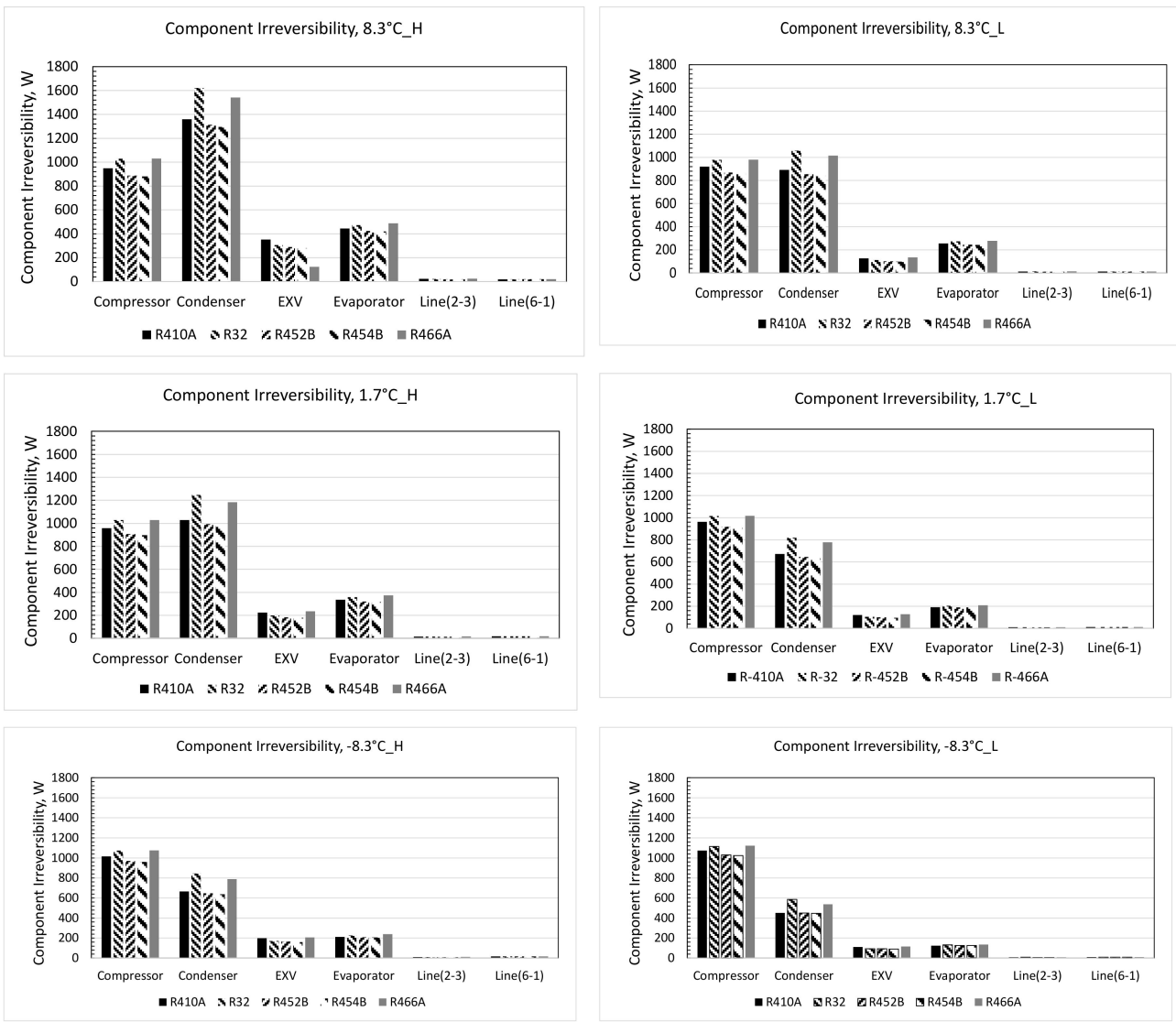

Figure 7. Irreversibility structure of heat pump components at ambient temperatures specified by the Air-Conditioning, Heating, and Refrigeration Institute (AHRI) 210/240 standard. Space heating temperature in all cases is at $21.1^{\circ} \mathrm{C}$, as per the standard. Lines (6-1) and (2-3) refer to connecting lines from the evaporator exit. 
The comparative irreversibility (Figure 8, left) and the heating COP relative to Carnot (Figure 8, right) of all refrigerants at each AHRI 210/240 standard rated condition is even more telling. Although all refrigerants perform relatively similar on a comparative basis, the irreversibility of R452B and R454B are consistently lower than that of the others. Regarding performance relative to Carnot (Figure 8, right), the pattern is unescapable when going from low temperature $\left(-8.3^{\circ} \mathrm{C}\right)$ to the high temperature $\left(16.7^{\circ} \mathrm{C}\right)$. At $16.7^{\circ} \mathrm{C}$, the Carnot heat pump efficiency is large, making the relative efficiency small as compared with the Carnot efficiency. The opposite is true at a low temperature where both the Carnot and the heat pump efficiency are smaller, making their ratio larger.
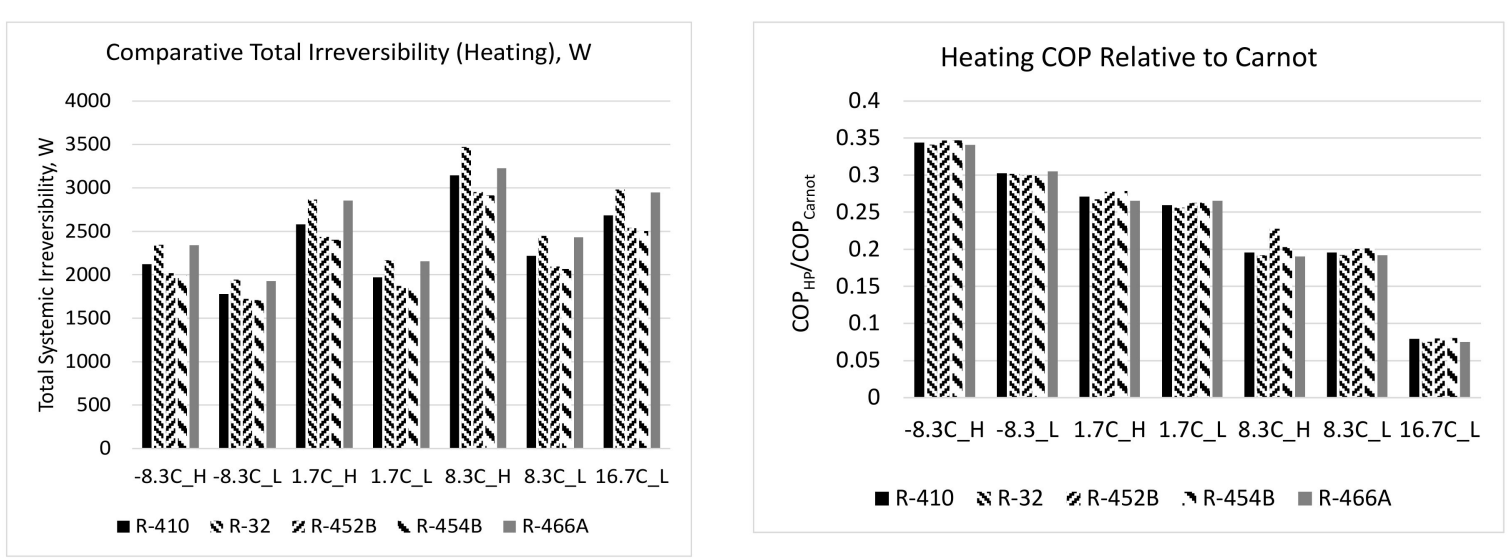

Figure 8. Performance of refrigerants in the HP (left) at various AHRI 210/240 standard rated conditions, and (right) as compared with the Carnot efficiency at the same rated conditions.

\section{Results and Discussion}

Our analyses based on the AHRI 210/240 standard rated conditions indicate that low-GWP refrigerants, listed in Table 1 are valid replacements for R410A based on better efficiencies and lower exergy losses. R32 has the best heat transfer performance and requires the smallest compressor for delivering the same capacity, supported by previous studies [22]. The condenser duty of R466A is the greatest among all other refrigerants (Tables 5-8). The higher condenser duty is reflected in slightly higher condenser irreversibility losses. Compressor irreversibility losses in high speed are generally greater than at low speed at the same rating conditions (Figure 7). Depending on the ambient conditions, the most irreversible component may be the compressor or the condenser unit (Figure 7). Irreversibility losses in both, evaporator and EXV are low. Irreversibility losses in the connecting lines are negligible and mainly due to thermal losses. The losses in the connecting lines between the compressor and the indoor coil are greater than the losses between the evaporator and the compressor inlet due to the relative distances. These losses, though small, could be further mitigated with better thermal insulation. Opportunities for reducing the irreversibility losses in the condenser could involve improved design and lowering of the condenser temperature, albeit at the expense of reducing some condenser duty. Differences in COPs of the heat pump for the refrigerants at the respective rating conditions were small, but the Carnot efficiency trended higher when the temperature lift was smaller. That is why the COP relative to the Carnot COP (Figure 8) gradually trended lower with rising ambient temperatures (corresponding to smaller temperature lifts). The calculation of the actual compressor work and that obtained from the HPDM model are in very good agreement. The agreement in the energy balances obtained from the model and by using the state points with corresponding values of state variables using REFPROP 10 are in excellent agreement, ranging from being exact to a maximum discrepancy of $\sim 0.6 \%$ (see $\% \Delta \mathrm{E}$ values in Tables $5-8$ ). The discrepancy is due to the convergence criteria in the HPDM program when it needs to be relaxed somewhat to get convergence. 


\section{Conclusions}

It is technically feasible to replace R410A with low-GWP refrigerants without changing the heat pump hardware. The candidate low-GWP refrigerants have better efficiency and performance characteristics relative to R410A. The energy input to the compressor, systemic irreversibility, and the condenser duty are important considerations before selecting a refrigerant. R32 and R454B have the lowest irreversibility. R466A has slightly greater irreversibility but a larger condenser duty. The component-wise irreversibility, shown in Figure 7, is crucial for understanding the sources of systemic irreversibility within the cycle. It is here that improvements should be made to make the heat pump even more efficient. Changeover to low-GWP refrigerants is a practical pathway towards mitigating GHG releases into the atmosphere without sacrificing energy efficiency. Heat exchanger design modifications to reduce irreversibility can be made based on exergy analysis for additional improvements.

Author Contributions: B.S. performed the modeling and simulations using the heat pump design model; M.R.A. performed the exergy analysis based on the state properties obtained from the simulations and modeling effort. All authors have read and agreed to the published version of the manuscript.

Funding: Funding was provided by the U.S. Department of Energy, Building Technologies Office

Acknowledgments: We are grateful to Antonio Bouza, Program Manager for the Emerging Technologies office related to heating, ventilation, air conditioning, refrigeration, and appliances for his support and encouragement.

Conflicts of Interest: This manuscript has been authored by UT-Battelle, LLC, under contract DE-AC05-00OR22725 with the U.S. Department of Energy (DOE). The U.S. government, and the publisher by accepting the article for publication, acknowledges that the U.S. government retains a nonexclusive, paid-up, irrevocable, worldwide license to publish or reproduce the published form of this manuscript, or allow others to do so, for U.S. government purposes. The DOE will provide public access to these results of federally sponsored research in accordance with the DOE Public Access Plan (http://energy.gov/downloads/doe-public-access-plan).

\section{Nomenclature}

$\begin{array}{ll}\text { AHRI } & \text { Air-Conditioning, Heating, and Refrigeration Institute } \\ \text { COP } & \text { Coefficient of performance, dimensionless } \\ \text { CV } & \text { Control volume } \\ \text { D } & \text { Density } \\ \text { EXV } & \text { Expansion valve } \\ \text { E } & \text { Energy, W } \\ \% \Delta \text { E } & \text { Percent energy change relative to input energy, dimensionless } \\ \text { g } & \text { Gravitational acceleration, } \mathrm{m} \cdot \mathrm{s}^{-2} \\ \text { GWP } & \text { Global warming potential } \\ \text { h } & \text { Enthalpy, } \mathrm{kJ} \cdot \mathrm{kg}^{-1} \\ \mathrm{~h} & \text { Heat transfer coefficient, } \mathrm{W} / \mathrm{m}^{2} / \mathrm{K} \\ \mathrm{I} & \text { Irreversibility, } \mathrm{W} \\ \mathrm{m} & \text { Mass flow rate, } \mathrm{kg} \cdot \mathrm{h}^{-1} \\ \mathrm{Q} & \text { Thermal exchange, } \mathrm{W} \\ \mathrm{Sp} & \text { Compressor speed } \\ \mathrm{T} & \text { Temperature, } \mathrm{K} \\ \mathrm{V} & \text { Volume } \\ \mathrm{v} & \text { Velocity, } \mathrm{m} \cdot \mathrm{s}^{-1} \\ \mathrm{~W} & \text { Work, W } \\ \text { z } & \text { Height above datum, } \mathrm{m} \\ \text { Subscripts } & \\ a & \text { Actual, or air } \\ \text { Carnot } & \text { Carnot } \\ \text { Comp. } & \text { Compressor } \\ & \end{array}$




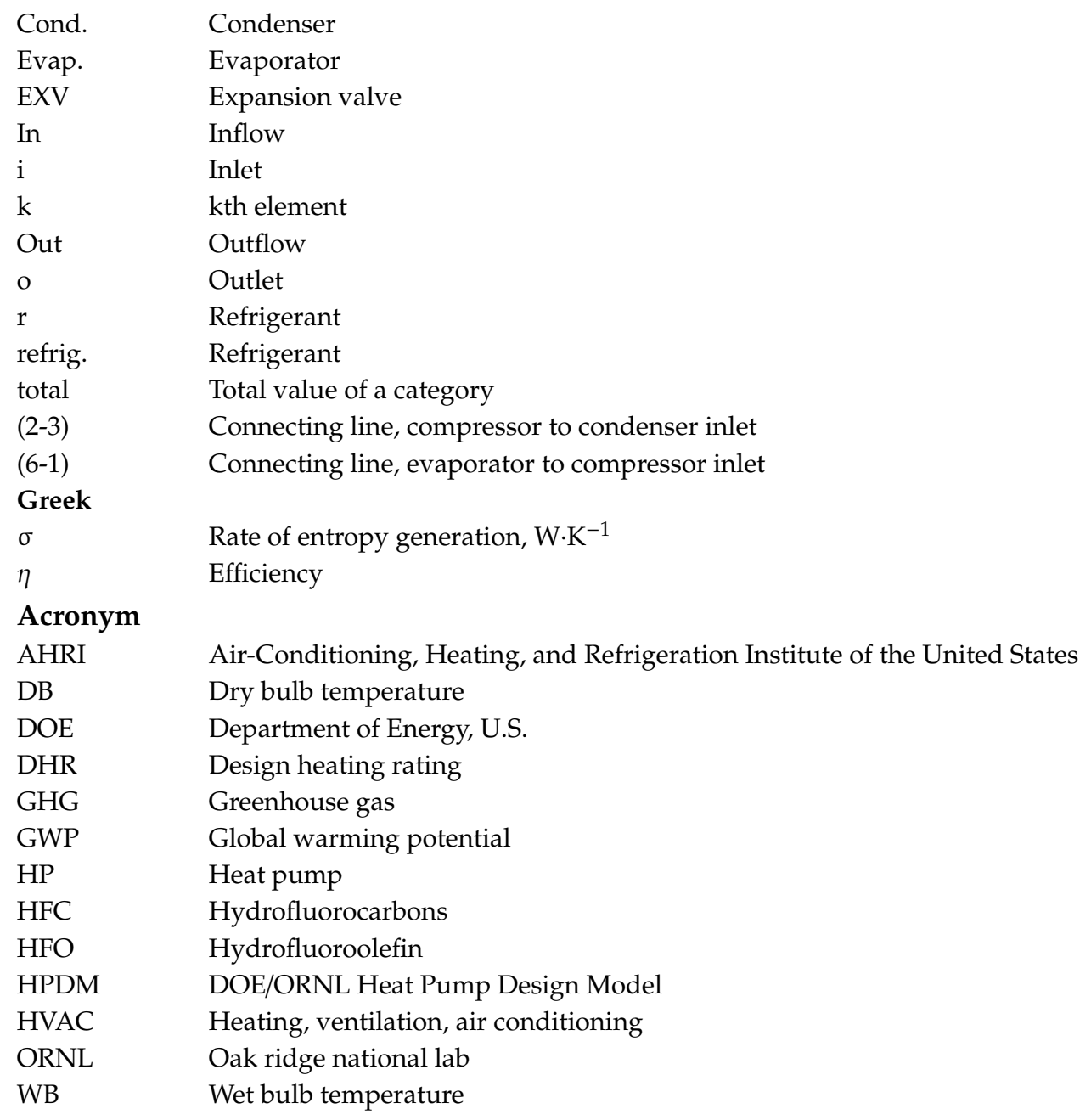

\section{References}

1. Ustaoglu, A. Parametric study of absorption refrigeration with vapor compression refrigeration cycle using wet, isentropic and azeotropic working fluids: Conventional and advanced exergy approach. Energy 2020, 117491. [CrossRef]

2. Espinel Blanco, E.; Valencia Ochoa, G.; Duarte Forero, J. Thermodynamic, Exergy and Environmental Impact Assessment of S-CO2 Brayton Cycle Coupled with ORC as Bottoming Cycle. Energies 2020, 13, 2259. [CrossRef]

3. Bonati, A.; De Luca, G.; Fabozzi, S.; Massarotti, N.; Vanoli, L. The integration of exergy criterion in energy planning analysis for 100\% renewable system. Energy 2019, 174, 749-767. [CrossRef]

4. Morosuk, T.; Tsatsaronis, G. Advanced exergy-based methods used to understand and improve energy-conversion systems. Energy 2019, 169, 238-246. [CrossRef]

5. Șoimoșan, T.M.; Moga, L.M.; Danku, G.; Căzilă, A.; Manea, D.L. Assessing the Energy Performance of Solar Thermal Energy for Heat Production in Urban Areas: A Case Study. Energies 2019, 12, 1088. [CrossRef]

6. Bai, T.; Yan, G.; Yu, J. Thermodynamic assessment of a condenser outlet split ejector-based high temperature heat pump cycle using various low GWP refrigerants. Energy 2019, 179, 850-862. [CrossRef]

7. Devecioğlu, A.G.; Oruç, V. Improvement on the energy performance of a refrigeration system adapting a plate-type heat exchanger and low-GWP refrigerants as alternatives to R134a. Energy 2018, 155, 105-116. [CrossRef]

8. Mota-Babiloni, A.; Belman-Flores, J.M.; Makhnatch, P.; Navarro-Esbrí, J.; Barroso-Maldonado, J.M. Experimental exergy analysis of R513A to replace R134a in a small capacity refrigeration system. Energy 2018, 162, 99-110. [CrossRef] 
9. Çakır, U.; Çomaklı, K.; Çomaklı, Ö.; Karslı, S. An experimental exergetic comparison of four different heat pump systems working at same conditions: As air to air, air to water, water to water and water to air. Energy 2013, 58, 210-219. [CrossRef]

10. Feidt, M.; Costea, M. Energy and Exergy Analysis and Optimization of Combined Heat and Power Systems. Comparison of Various Systems. Energies 2012, 5, 3701. [CrossRef]

11. Bayrakçi, H.C.; Özgür, A.E. Energy and exergy analysis of vapor compression refrigeration system using pure hydrocarbon refrigerants. Int. J. Energy Res. 2009, 33, 1070-1075. [CrossRef]

12. Kabul, A.; Kizilkan, Ö.; Yakut, A.K. Performance and exergetic analysis of vapor compression refrigeration system with an internal heat exchanger using a hydrocarbon, isobutane (R600a). Int. J. Energy Res. 2008, 32, 824-836. [CrossRef]

13. Kaygusuz, K.; Ayhan, T. Exergy analysis of solar-assisted heat-pump systems for domestic heating. Energy 1993, 18, 1077-1085. [CrossRef]

14. Cervantes, J.G.; Torres-Reyes, E. Experiments on a solar-assisted heat pump and an exergy analysis of the system. Appl. Therm. Eng. 2002, 22, 1289-1297. [CrossRef]

15. Suleman, F.; Dincer, I.; Agelin-Chaab, M. Energy and exergy analyses of an integrated solar heat pump system. Appl. Therm. Eng. 2014, 73, 559-566. [CrossRef]

16. Aprea, C.; Greco, A. An exergetic analysis of R22 substitution. Appl. Therm. Eng. 2002, 22, 1455-1469. [CrossRef]

17. Lakew, A.A.; Bolland, O. Working fluids for low-temperature heat source. Appl. Therm. Eng. 2010, 30, 1262-1268. [CrossRef]

18. Talbi, M.M.; Agnew, B. Exergy analysis: An absorption refrigerator using lithium bromide and water as the working fluids. Appl. Therm. Eng. ring 2000, 20, 619-630. [CrossRef]

19. Ghazizade-Ahsaee, H.; Ameri, M. Energy and exergy investigation of a carbon dioxide direct-expansion geothermal heat pump. Appl. Therm. Eng. 2018, 129, 165-178. [CrossRef]

20. Byrne, P.; Ghoubali, R. Exergy analysis of heat pumps for simultaneous heating and cooling. Appl. Therm. Eng. 2019, 149, 414-424. [CrossRef]

21. Thome, J.R.; Ei Hajal, J. Two-Phase Flow Pattern Map for Evaporation in Horizontal Tubes: Latest Version. In Heat Transfer Engineering; Taylor \& Francis: Kruger Park, South Africa, 2010; Volume 24, pp. 1-2. [CrossRef]

22. Shen, B.; Abdelaziz, O.; Shrestha, S.; Elatar, A. Model-Based Optimizations of Packaged Rooftop Air Conditioners Using Low Global Warming Potential Refrigerants. Int. J. Refrig. 2018, 87, 106-117. [CrossRef]

23. Shen, B.; Rice, K. DOE/ORNL Heat Pump Design Model. 2016. Available online: http://hpdmflex.ornl.gov/ (accessed on 6 September 2020).

24. ANSI/AHRI Standard 540-99. Positive Displacement Refrigerant Compressors and Compressor Units; Air Conditioning and Refrigeration Institute: Arlington, VA, USA, 2010.

25. Dabiri, A.E.; Rice, C.K. A Compressor Simulation Model with Corrections for the Level of Suction Gas Superheat. ASHRAE Trans. 1981, 87 Pt 2,771-782.

26. Braun, J.E.; Klein., S.A.; Mitchell, J.W. Effectiveness models for cooling towers and cooling coils. ASHRAE Trans. 1989, 95 Pt 2, 164-174.

27. Cavallini, A.; Col, D.D.; Doretti, L.; Matkovic, M.; Rossetto, L.; Zilio, C.; Censi, G. Condensation in Horizontal Smooth Tubes: A New Heat Transfer Model for Heat Exchanger Design. Heat Transfer Eng. 2006, 27, 1-38. [CrossRef]

28. Choi, J.Y.; Kedzierski, M.A.; Domanski, P.A. Generalized pressure drop correlation for evaporation and condensation in smooth and micro-fin tubes. Proc. IIF-IIR Commision B 2001, 1, 9-16.

29. Rouhani, S.Z.; Axelsson, E. Calculation of void volume fractions in subcooled and quality boiling regimes. Int. J. Heat Mass Transf. 1970, 13, 383-393. [CrossRef]

30. Stephan, K. Heat Transfer in Condensation and Boiling; Springer: New York, NY, USA, 1992; p. 84.

31. Bell, K.J. An approximate generalized design method for multicomponent/partial condensers. In AIChE Symposium Series; American Institute of Chemical Engineers: New York, NY, USA, 1972; Volume 69, pp. 72-79.

32. Lemmon, E.W.; Bell, I.H.; Huber, M.L.; McLinden, M.O. NIST Standard Reference Database 23: Reference Fluid Thermodynamic and Transport Properties-REFPROP, Version 10.0; National Institute of Standards and Technology, Standard Reference Data Program: Gaithersburg, MD, USA, 2018.

33. Standard AHRI. 210/240-2008. Performance Rating of Unitary A/C and Air Source Heat Pump Equipment; Air-Conditioning, Heating \& Refrigeration Institute: Arlington, VA, USA, 2008. 
34. Warke, K., Jr. Advanced Thermodynamics for Engineers; McGraw-Hill: New York, NY, USA, 1995; ISBN 0-07-068292-5.

35. Ally, M.R.; Sharma, V.; Nawaz, K. Analysis of the P-T and T-S phase boundary in discriminating suitable low global warming potential and low flammability refrigerants. In Refrigeration Science and Technology Proceedings, Proceedings of the 25th IIR International Congress of Refrigeration, Montreal, QC, Canada, 24-30 August 2019; International Institut of Refrigeration: Paris, France, 2019; pp. 804-810. ISBN 978-2-36215-035-7. [CrossRef]

36. Ally, M.R.; Munk, J.D.; Baxter, V.D.; Gehl, A.C. Exergy analysis and operational efficiency of a horizontal ground-source heat pump system operated in a low-energy test house under simulated occupancy conditions. Int. J. Refrig. 2012, 35, 1092-1103. [CrossRef]

37. Ally, M.R.; Munk, J.D.; Baxter, V.D.; Gehl, A.C. Exergy and energy analysis of a ground-source heat pump for domestic water heating under simulated occupancy conditions. Int. J. Refrig. 2013, 36, 1417-1430. [CrossRef]

Publisher's Note: MDPI stays neutral with regard to jurisdictional claims in published maps and institutional affiliations.

(C) 2020 by the authors. Licensee MDPI, Basel, Switzerland. This article is an open access article distributed under the terms and conditions of the Creative Commons Attribution (CC BY) license (http://creativecommons.org/licenses/by/4.0/). 